\title{
Reasons that Stops Long-Term Unemployed Social Benefits Receivers from Returning into Labour Market
}

\author{
Anna Bickovska Mg. ed. \\ Latvia University of Life Sciences and Technologies, Latvia \\ annabickovska@gmail.com
}

\begin{abstract}
There is part of society that still misuse social security system and remain unemployed for very long period in a society where it is possible to find a job and be employed constantly. A variety of services and professional help is offered to long-term unemployed social benefits receivers to improve their social situation. The aim of the study was to define the reasons that stop long-term unemployed social benefits receivers to enter labour market even if economic and social situation in Latvia allows it. Forty-seven long-term unemployed social benefits receivers were asked to fill in the questionnaire to get information about reasons that stop them from entering labour market (what stops them from entering the labour market, what kind of help/service they need to do so). Twenty-eight of the respondents answered that there is no proper job offer in the market, fifteen of the respondents answered that they don't have adequate education to fit into modern labour market, four respondents mentioned that they have other obstacles that don't allow them to work. The results show that long-term unemployed social benefits receivers are not willing to enter labour market because of their inadequate self-esteem and inadequate wishes about the job and salary; many of them consider living on social benefits more profitable than spending long shifts at work.
\end{abstract}

Keywords: adult education, unemployed, long-term unemployed, career education, career services.

\section{Introduction}

The aim of the study is to define the reasons that stop long-term unemployed social benefits receivers from being employed in a situation when there are many offers out on the labour market. Numerous amount of services is offered to them in order to get additional education, certification, training. All of them are registered at State Employment Agency and are eligible for free career counsellor sessions. The long-term unemployed social benefits receivers are able-bodied persons who have received monthly benefits for more than 12 times within the last three years and were jobless at least 9 months (Bickovska, 2016), and have been receiving social service support at least for the last six months. The level of unemployment varies in different regions of Latvia, in the $3^{\text {rd }}$ quarter of 2017 Latvian unemployment rate constituted $8.5 \%$ (In the 3rd..., 2017), which means that it is possible to be employed.

Reflecting on the idea that some people prefer to stay unemployed for years in a situation when it is possible to get a job seems a bit controversial. The reasons for being unemployed are something more than social circumstances, a lot of people suffer from untreated psychiatric illnesses, many people (especially in regions) are suffering from addiction problems (alcohol). Speaking about numbers of long-term unemployed it is important to remember that a lot of 'official' long-term unemployed are working illegally in order to maintain their status because of the social benefits they are entitled to with such a status (Scientific research..., 2014). When working with long-term unemployed social benefits receivers, professionals cannot separate those ones who are in need and those who are employed illegally, if they are attending some activities they are eligible to receive the service they want. Professionals, as part of a modern democratic society, need to provide the services even if they feel that clients are not truly interested in that.

According to the Europe 2020 strategy first priority is human resilience. That concept includes human capability to adapt and change according to fast changing environment - personal initiative, ability to cooperate - defining traps for personal development. According to that plan the main working areas for government and institutions (among many others) are providing employment and income, lifelong education, promoting creative and process understanding individual (Europe 2020..., 2010). Not only socially-economic situation motivates individuals to look for a job, but they are also willing to get the approval that they can manage different tasks and bring joy to other people (Strebler, Bevan, 1996). Being unemployed and not successful in that field for many years brings negative changes to personality that will affect the reasons for staying unemployed and individual's ability to think about it critically. 
Another reason might be that nowadays employers are looking for qualified workers more often, a lot of long-term unemployed social benefits receivers are not eligible for that; since technologies are taking huge part of our lives some of the long-term unemployed are not able to fit into the new reality and gain new skills. Most of the long-term unemployed social benefits receivers are not connected to the real labour market that exists nowadays - to the tools and methods they need and the amount of money the can earn spending at least 8 hours at work (Supule et al, 2015).

Different institutions that are involved in work with long-term unemployed social benefits receivers (especially those ones providing educational activities) should take into consideration adults' needs in education, those adults who are suffering from negative impact for years. Adults need education not only in terms of their unemployment, but also as part of a lifelong education concept - lifelong education motivates individuals to acquire new skills, knowledge and opportunities that can be used not only in work life, but also improve their life skills in general (Draft UNECE Strategy..., 2004).

The main goal of the education process is the process itself, but not the result - this D. Kolb's idea, as a part of experiential learning theory is the best way of describing education for long-term unemployed social benefits receivers (Kolb, 2015). Adults learn, firstly, through their experience, but educators need to take into consideration that for the last few years their experience was, mainly, negative. The educator needs not only to be a professional in his field, but also a good therapist in order to help long-term unemployed social benefits receivers to start looking at themselves and their environment in another way.

Every change starts with inner motivation, but long-term unemployed social benefits receivers lack it, they cannot get some special training for it in Latvia. When speaking with the respondents, most of the time they mention only outer motivation - bigger salary, better work condition, but none of them mentioned inner motivation that relates to personal development aspects (Koen, Klehe, Vianen, 2013). Living in modern society, we should accept idea that not everybody wishes to work, since there are opportunities to exist on social benefits.

\section{Methodology}

A survey developed by the author consists of 3 questions which represent respondents' attitude toward themselves, their opportunities and reasons to get employed or staying unemployed, what kind of services they need to help them. The participants were also asked to specify their gender, age, period of unemployment and level of education.

Questions respondents were asked to answer:

1. What stops you from getting employed?

2. What kind of support do you need to enter labour market?

3. Have you ever used professional help (career counsellor, social worker, and therapist) to get employed?

The current empirical research was carried out in one of Riga Social Service departments. 47 long-term unemployed social benefits receivers took part in this research. The participants of research were the following: 36 females $(76.6 \%)$ and 11 males $(23.4 \%$ ) between the age of 23 to 59 (Mean $(\mathrm{M})=40.88$, Standard Deviation $(\mathrm{SD})=10.1$ ).

\section{Results and Discussion}

Being unemployed for many years in a row brings significant changes to an individual's personality that can't be cured during some short intervention, in order to be treated individual needs to receive a longterm therapy. It is not possible to receive it for free (from local municipality of any kind of institutions), so it means a lot of money - it is a barrier for long-term unemployed social benefits receiver. Obviously, nothing starts from therapy, individual needs to be motivated to change his/her life but living in need and self-destructive way for many years, there is quite a low possibility of having strong inner motivation. Working with these type of clients, professionals should be extra patient and full of energy and willing to help, but the important thing is to remember that you can't help those who are not seeking help - it should be a moto for everyone who works with people.

The background of the 47 respondents, who are long-term unemployed, shows that most of them have secondary education (36 respondents), 7 of them have higher education and only 4 of them have primary education. Unemployment periods vary starting from 24 months to 68 months. 


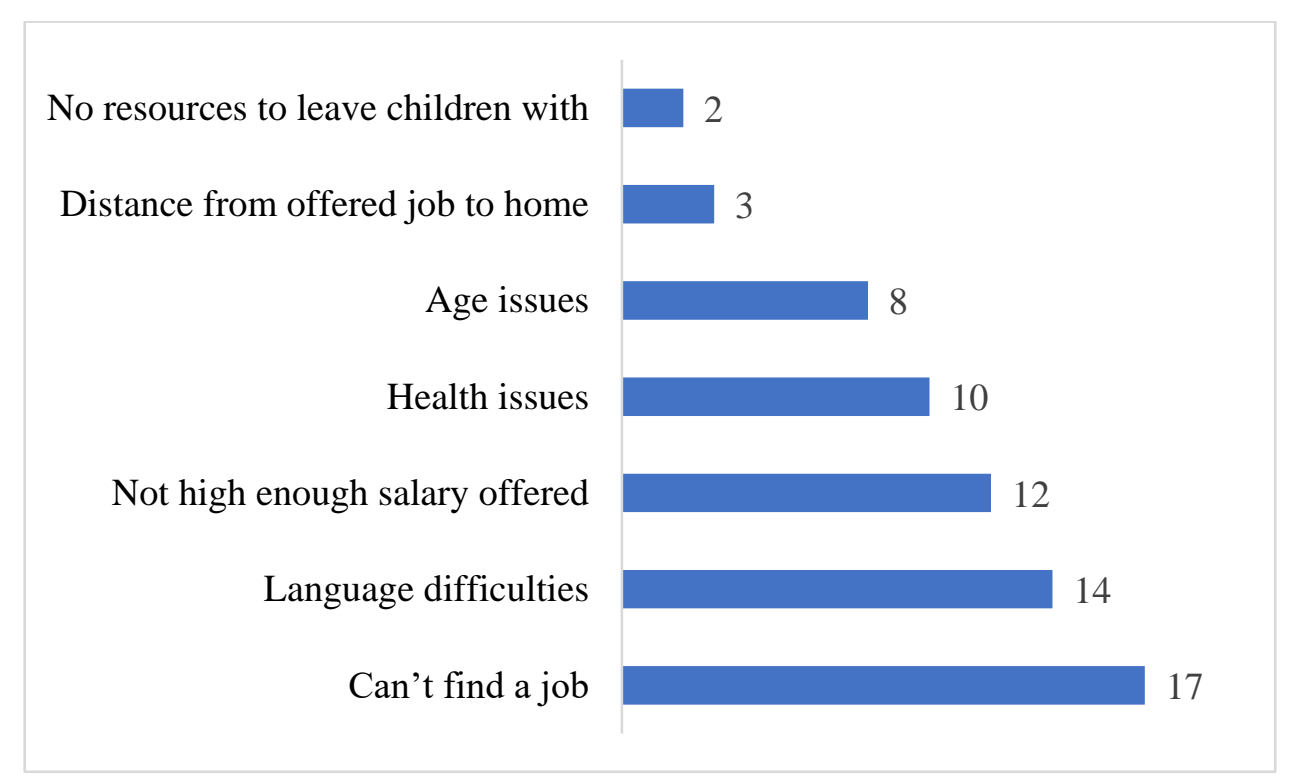

Figure 1. Reasons that stops from getting employed $(n=47)$.

According to the Figure 1, answering the first question "What stops you from getting employed?" 17 respondents replied that they can't find a job, 14 replied that they can't get employed because of a lack of language skills (it is obligatory to know Latvian language in Latvia in order to get employed, employee need to have certificate that proves knowledge - for many middle aged Russian speaking inhabitants it is a problem); 12 respondents mentioned that the salary that was offered to them is not high enough for leaving social benefits system and move forward onto independent life (that's the sign of inadequate self-esteem, because most of the respondents have secondary education and no professional qualification). Ten respondents mentioned health issues, health services are paid by the clients themselves in Latvia, not only fee is a reason that stops clients from visiting health care institutions but also long queues. It is almost impossible to get to the doctor you need in a few days' time or at least weeks. Normally, to get an appointment the average waiting time would be 1 to 2 months. Especially expensive are dental services - those are not available for long-term unemployed social benefits receivers. Health issues may differ in it is nature - one part of them without proper treatment may transfer into disability, another can by cured. Eight respondents (all women) mentioned that their age is the reason that stops them from being employed - they were rejected because they are at preretirement age. Only 3 people mentioned that the job they were offered was far away from the place they are live, that might be a reason only in case of a very specific job and qualification, in other cases there are a lot of job offers all around Riga. Two women mentioned that the reason of being unemployed are children or no relatives to leave the children with. This reason might be real, for it might take about 2,5 to 3 years to get a place at kindergarten for a child in Riga.

Answering the second question, "What kind of support do you need to enter labour market?" 17 respondents mentioned that they need additional education/training ( 9 women, 8 men), 15 respondents ( 10 women and 5 men) mentioned that they need additional language training (in Latvia it is the case of a lot Russian speaking inhabitants who can't get employed without knowing Latvian language), 4 respondents (only women) mentioned that they need therapy (psychologic sessions), two respondents ( 9 women) mentioned that they need additional babysitting service (kindergarten or alternative). All these answers support the idea that all that long-term unemployed social benefits receivers consider as needed is partly provided by local government (education and training (language training as well) are provided by State Employment Agency, therapy is possible to get via Social Service, for babysitting there are few options - get a place in kindergarten, get financial subsidy for private kindergarten or for private babysitter); only health care support is not provided for free from any kind of organization. Most of the reasons that stop long-term unemployed social benefits receivers from being unemployed can be solved, so it is possible to change reasons or even to prevent if intervention is done at the early stages. Latvian system and organizations that are involved into support services for long-term unemployed are not a miracle and are not created to help everyone immediately, but they offer quite a range of possibilities for unemployed to get back onto labour market sooner or later. 
Per the research made in 2007 "Reasons of unemployment and social exclusions in Latvia" (Bezdarba un socialas.... 2007) more stress should be placed over State Employment Agency in order to provide more opportunities for unemployed to educate, as we can see now, in 2017, 10 years later variety of services provided by State Employment Agency for different target groups has grown at least twice since then.

Answering the third question all respondents mentioned that they at least once used professional support, respondents have mentioned such professional as social worker, career counsellor, psychologist, State Employment Agency worker.

To sum up, average long-term unemployed is quite acquainted with all the services and system in general that are created for them, they are using it, or at least are trying to do everything to stay in that system. When speaking about long-term unemployed social benefits receivers the first thing to remember is financial profit they prefer to stay in that kind of situation because they can get more social benefits and more financial support, a lot of them are working illegally.

Of course, a big part of this group is truly unemployed for many years in a row and is trying to survive, they have a variety of complex problems, a big part of them is mental, that special state of mind that stops them from moving forwards. They were managing their marginalized career for years and they need a very strong will to change it and a very good team of professionals that would be able to help them, because it is not only a job for social worker or career counsellor, all of them should be involved in a process and only a team work can bring visible result.

Strong will and inner motivation is a key to success. According to L. Shulman "Motivation is one of the crucial preconditions for learning" (Shulman, 1987). All of the respondents have attended different types of educational programs (re-education programs, additional language or professional courses), but they continue to remain unemployed, which shows that:

- educational programs are not effective if a person is not able to get employed after attending it;

- individuals do not have any inner motivation in order to use their new skills and knowledge for job searching and continue to remain unemployed, so they attend courses only under the pressure of State Employment Agency.

Motivation is the hardest aspect to change and to influence for professionals, there is not a big opportunity for long-term unemployed social benefits receivers to change their lifestyle and get back to labour market, to change their social life and relationships. It is widely known, struggle in a job context impacts not only the job itself - it brings complications to relationships with family, with themselves; brings severe changes to personality itself. Few theories explain motivation phenomenon and how to affect it, most of them are highly cognitive, so it can be very frustrating (Krumboltz, Levin, 2004) to use them in work with long-term unemployed social benefits receivers since they are mostly acting according to behavioural theories.

According to M. Jahoda's theory, long-term unemployed social benefits receivers can be very satisfied with their situation and life rhythm (Jahoda, Lazarsfeld, Zeisel, 2017). They are satisfied with their lifestyle because they do not have that strict structure of life that is created by job and other business timing. Typical long-term unemployed feels the time differently than average working person - they are not able to arrange many appointments on one day, in general, their time is flowing much slower than for others. Another reason of being unemployed is their wish to stay in the same state and live the life as they prefer and able to manage.

\section{Conclusions}

The reasons that stop long-term unemployed social benefits receivers are different, but none of them is not changeable. Most of the time it's some deep problems that can be stated in few words and need treatment and constant supervising, some of the times long-term unemployed social benefits receivers are working illegally and are just not interested in changing their lifestyle, but there are some aspects that might be used in future researched or direct work with clients:

- long-term unemployed social benefits receivers are using all possible services - State Employment Agency services, social worker consultations (and Social service in general), 
career counsellor consultations as they still remain unemployed and that means that all these services haven't reached their goal;

- long-term unemployed social benefits receivers mentioned quite a few services that they need in order to re-enter labour market, but all of these services (except health service) are available right now and are free of charge - that means that they are not able to use resources and information they are given or are not interested in it;

- all the reasons long-term unemployed social benefits receivers mentioned as their reasons staying at the same state are not critical and can be solved with a help of professional or even without it, having low unemployment rate and variety of services (additional education, treatments, career counselling) it is possible to find a job if it is high priority for individual;

- when working with long-term unemployed social benefits receivers it is obligatory to remember that for some of them their lifestyle is a state of mind for them and they are simply not willing to change it, but still are trying to look for some reasons that they would be able to present to society;

- the author considers one of the main but unnamed reasons of staying unemployed is a lack of inner motivation to move forward and bring changes to life.

\section{Bibliography}

1. Bickovska A. (2016). Job Searching Habits of Long-Term Unemployed Social Benefit Receivers in Latvia. Baltic Journal of Career Education and Management, 4 (1), 8-14. Retrieved from http://oaji.net/articles/2017/453-1486411433.pdf

2. Draft UNECE Strategy for Education for Sustainable Development. (2004). Geneva: UN Economic Commission for Europe, Committee on Environmental Policy. Retrieved from http://www.unece.org/fileadmin/DAM/env/documents/2004/cep/ac.13/cep.ac.13.2004.8.rev.1.e.pdf

3. Europe 2020: A European Strategy for Smart, Sustainable and Inclusive Growth. (2010). Brussels: European Commission. Retrieved from http://ec.europa.eu/eu2020/pdf/COMPLET\%20EN\%20BARROSO\%20\%20\%20007\%20\%20Europe\%202020\%20-\%20EN\%20version.pdf

4. In the 3rd quarter of 2017, Latvian unemployment rate fell by 0.4 percentage points. (2017). Riga: Central Statistical Bureau. Retrieved from http://www.csb.gov.lv/en/notikumi/3rd-quarter-2017latvian-unemployment-rate-fell-04-percentage-points-47062.html

5. Jahoda M., Lazarsfeld P.F., Zeisel H. (2017). Marienthal: The Sociography of an Unemployed Community. New York: Routledge, Taylor and Francis Group.

6. Koen J., Klehe U.C., Vianen E.M. (2013). Employability among the long-term unemployed: A futile quest or worth the effort? Journal of Vocational Behavior, 82(1), 37-48. Retrieved from http://www.sciencedirect.com.ezproxy.llu.lv/science/article/pii/S0001879112001418

7. Kolb D.A. (2015). Experiential Learning: Experience as the Source of Learning and Development. $\left(2^{\text {nd }}\right.$ ed. $)$. New Jersey: Pearson Education.

8. Krumboltz J.D., Levin A.S. (2004). Luck is no accident: Making the most of happenstance in your life and career. Atascadero, CA: Impact Publishers.

9. Scientific research: Latvia: "Who is Unemployed, Inactive or Needy? Assessing Post-Crisis Policy Options". (2014). Washington, D.C., US: The World Bank. Retrieved from http://www.lm.gov.lv/upload/aktualitates/lv_profiling_270513.pdf

10. Shulman L.S. (1987). Knowledge and teaching: Foundations of the new reform. Harvard Educational Review, 57(1), 1-22.

11. Strebler M.T., Bevan S. (1996). Competence-Based Management Training. Brighton, UK: University of Sussex, The Institute for Employment Studies. Retrieved from http://www.employment-studies.co.uk/system/files/resources/files/302.pdf

12. Supule I., Zabko O., Bebrisa I., Klave E., Jansone L. (2015). Petijums par administrativa sloga samazinasanas iespejam un inovativam pieejam ilgstosa bezdarba problemu risinasana (A Study on Reducing Administrative Burdens and Innovative Approaches in Addressing Long-term Unemployment). Riga: Baltic Institute of Social Sciences. Retrieved from http://www.mk.gov.lv/sites/default/files/editor/4._gala_zinojums_29.07.2015.pdf (in Latvian) 